\title{
PROBLEM OF PRESERVATION THE HISTORIC MONASTERY IN NOVY ZAGORIV
}

\section{ПРОБЛЕМА ЗБЕРЕЖЕННЯ ІСТОРИЧНОГО МОНАСТИРЯ В НОВОМУ ЗАГОРОВІ}

(C) Chen L., 2020

Розглянуто архітектурно-просторовий устрій монастиря Різдва Богородиці в Загорові. Прослідковано еволюцію його розвитку та визначено етапи розвитку будівництва монастиря. Проведено натурні обстеження монастирських споруд. На основі аналізу технічного стану монастирських будівель, щцо дійили до нашого часу, розроблено реставраційні заходи щодо збереження пам'ятки.

Ключові слова: монастирський комплекс, церква Різдва Богородиці, монастирський келійний корпус, натурні обстеження, реставраційні заходи.

The architectural and spatial arrangement of the monastery in Novyi Zagoriv is considered. The evolution of its development has been defined and the stages of the monastery's development have been determined. Observation of monastic structures were conducted. Based on the analysis of the technical condition of the monastery buildings that have survived until today, the restoration approaches for preservation the monument have been developed.

Ключові слова: Monastery, Church of the Nativity of the Virgin, Monastery cell buildings, observation, restoration approaches.

\section{Problematic}

Monasteries that were not only centers of spirituality but centers of culture, art, science and education of our people, occupy a special place in the historic and town-planning heritage of Ukraine. They were prominent architectural complexes and ensembles that relate to the history of Ukraine and its regions. The same significance was given to the monastery of the Nativity of the Virgin in the village of Novyi Zagoriv, Lokachiv district in Volyn. On September 8-11, 1943, the Ukrainian Partisan Army(UPA) held defenses against the German gendarmerie in the walls of the monastery.

\section{Relevance of research}

Monasteries related with historical events and national liberation battles are often in a dilapidated or destroyed state. Such an architectural object is the monastic complex of Nativity of the Virgin Mary in Zagoriv in Volyn. Due to its artistic and aesthetic qualities, monastic buildings make an impression at the viewer and reveal the connection of the historical and cultural object 
with outstanding historical events. The problem of the revival of such historical monasteries, especially in our time, is extremely relevant.

\section{Purpose of the article}

Purpose is to analyze the process of formation of Zagorivsky monastic complex in different historical periods of its development, to show the existing state of the monastery and to develop a program of restoration approaches for preventing the further destruction of the historical monument.

\section{Analysis of recent research and publications}

Many researchers tried before to solve the problem of restoration of historic monastic complexes and ensembles such as Ye.Michailovsky, S.Podiapolsky, O.Prutsin, Ukrainian scholars Y.Aseev, G. Logvyn, M. Tsapenko, S. Kilesso. Valuable information concerning the restoration of monastic complexes and their structures is found in the works of Y. Vodzinskyi, O. Plamenytska, O. Godovanyuk, V. Tymofiyenko, T. Trehubova, I. Mohytych, L. Prybeha, V. Vecherskyi, O. Lesyk. Vast experience in preserving monuments takes into account local traditions and its features in publications of these researchers.

\section{Basic material}

Monastery complex of Nativity of the Virgin in Zagoriv is located on the southern outskirts of the village, on a high natural terrace, protected from the north and west by steep slopes of the hill above a small pond. The territory of the monastery surrounded by a fence. There is an entrance gate on the main axis of the monastery that is led by long brick stairs. The monastery complex consisted of the Church of the Nativity of the Virgin and enclosed to it the monastery cellar campus from the east. Before there were attached two-stories brick monastery building with a refectory from the south but, nowadays, nothing reminds of them. Today, the monastery is in a dilapidated state and consists of the Church of the Nativity of the Virgin and some remains of adjacent monastic corp. Two-stories monastic buildings destroyed during the Second World War at the south. In the north of the monastery church, there are burials of the Ukrainian partisans who died in the battle with the Germans in 1943. At the east of the monastery there is a modern rural cemetery while $n$ the south there is just an overgrown.

The history of the foundation of the monastery dates to the ancient times. According to local tradition Zagorivsky monastery was founded in the middle of the XIII century by Kiev-Pechersk monks who escaped from Batyev's invasion and brought with them a miraculous icon of the Mother of God (Крощенко, 1996, с.215). According to another version, the monastery was founded in the fifteenth century by Zimnensky monks (Kroshchenko, 1996, p. 215). More precise date of the founding of the monastery is XV century that was discovered at the inscription on the split bell:

“"З ласки Божии я, Олександро Юрьевич Загоровский и з женой своей Настасиею лета

7 тисяч (1492) придались по сей звон к монастыре в Загорове ку чти ку хвале Пречистой Божий Матери“ (Трипольский, 1892, с.107).

The founder of the monastery was Peter Bogdanovich Zagorovsky who began to build a new brick church in the honor of the Nativity of the Virgin and a wooden one-floor fraternal campus on the place of the wooden church, as a sign of gratitude for his healing from illness in front of the icon of the God's Mother. (Tripol'skiy, 1892, p.107). On-site inspections of church's remains were discovered an ancient altar part and the attached to it remains of the nave covered by groin vault and a conch. The detailed in-depth surveys of the church of the Nativity of the Virgin revealed the original church had a small hall type. According to the analysis of literary sources, it probably lasted 
until the middle of the XVII century. L. Kroschenko assumes the church after the reconstruction in the XVI century got cruciform plan with a tower on the west. Such a spatial composition of the monasteries was widespread in the western regions of Ukraine. At the second stage of the development of the monastery, two square ramens were completed from the south and north of the initial nave, as it seen in red brick masonry that have measures 30:14:8.5 $\mathrm{cm}$ and a gutter mortar bed. The masonry system is gothic on a lime mortar with a rubbing of wide joints (up to $3 \mathrm{~cm}$ ) by lozenges. So, the surface of the walls did not require molding and the patterned masonry has a special decorative effect. Because of the completion of the ramens church becomes triennial.

From archival sources of later documents dated 1804, it was found out: "There was once a tower clock (in the church), but after the destruction of the tower and the use of its material for the construction of the church, the remaining parts and clock wheels are waiting for the construction of the tower and the restoration of its mechanism" (Kroshchenko, 1996, p.215). Consequently, it can be assumed that the tower was built over the western part of the initial church during the completion of the third campus. After the reconstruction of the church in the seventeenth century, it got a cross-shaped planning system with a tower above the western part of the monastery.

At the end of the XVII century, a prominent artist Ieov Kondzeliewicz from Bialystok was invited to paint the iconostasis and the icon case for the icon of the God's Mother in the altar of church of the Nativity of the Virgin (Kroshchenko, 1996, p.215) (Fig. 3). The icon case was decorated with a gold-plated openwork carvings on a blue background. I. Kondzelevich depicted the figures of Joaquim, Anna and several compositions of the biblical and evangelical themes. The authorship of the artist testifies the inscription: "Humorous hieromonk Iov Kondzelevich, M. Zakonnik, S.M. Melnik in the summer of the God's year 1696" (Kroshchenko, 1996, p.215).

According to B. Voznitsky's assumption, the iconostasis was made by the carver Ivan Karpovich and painted by Ieov Kondzeliewicz and his disciples in 1722. The author's paintings include the icon of the Virgin-Odiigitriya, the Christ-Teacher, the icon of the apostles, the prophetic rows and the central icon of the iconostasis of Prayer (Deisus) that contains the date of the creation of the iconostasis in 1722, as well as the deacon's door with the image of the Archangel Michael and the Guardian, the icon of the Nativity of the Virgin, the Introduction to the Church, the Creator of the Savior, the icon of Anthony and Theodosius (Otkovich, 2011) (Fig. 4).

In the 1760's, the iconostasis was transferred to the Peter and Paul Church in Voshchatin where it was until 1969. Then it was transferred to the A. Sheptytsky National Museum of Ukrainian Art in Lviv.

In 1719 the monastery joined the Unia, switching from Orthodoxy to the Basilians. (Essay on the history of the Basilian Order of St. Jehoshaphat, 1992, p.97-336) Thereby, the significant changes took place in the interior of the church. There were built four altars: Jesus (1729), St. Joseph and St. Josaphat (1730), St. Basil (1738) that were decorated with artificial marble, polychrome and gildings with placed images of the saints written on the canvas (Kroshchenko, 1996, pp.216-217). The interior of the church was decorated with carved wooden gilded sculptures, plaster reliefs, the portrait and heraldic images (Fig. 3). The paintings were performed by Ostroh artist Ludwik Brendel in the 70's and Pochaiv painters Stepan-Sava Kalinovich and Andriy-Alipii Tokarevsky assisted him (Voznyts'kyy, 1967; Kudryts'kyy, ed., 1992, p.313).

The second stage of rebuilding the Church of the Nativity of Virgin began by monastic funds with the support of the founders Y.V.Shashny, Frantisk and the brothers Chatsky which admire the image of the Zagorivska Mother of God in 1763 (Kroshchenko, 1996, pp.216-217). The work lasted 17 years and further renewed monastery was consecrated by Bishop Simeon Mlotsky on May 3, 1780 (Kroshchenko, 1996, p.216). 
The reconstruction of the Church of the Nativity of the Virgin by Basilians radically changed the appearance of the building. As a result, it has become Roman Catholic Church. The church turned into a six-pillar basilica with an elevated central nave and an altar part, covered with groin vaults with stripping. Under the floor of a church between two pairs of pillars locates a crypt. The main western façade is executed in late Baroque style. It is divided horizontally by wide double cornices at three levels, decorated by pillars with pseudo-ionic capitals on the pedestals and decorative vases. The second and the third tiers are decorated with paintings (fig. 2). The entrance portal is framed by pylons with pseudo-ionic capitals on the pedestals on which the semi-circular arch supported. Monumental side facades are without a decor or any base. They simply completed by profiled cornice.

The next stage of the construction of Zagoriv Monastery dates from the late 18th and early 19th centuries. Two monastery corridor type cellar campuses with a refectory, a kitchen, a bakery, a barn, a library, an archive, a meeting room, a storage for clothes were constructed on monastic funds. Thus, it formed a closed internal space imitating a cloister. One-story school with three rooms, a kitchen and a pantry was attached to the southern campus on the place of the former refectory. Stone walls were erected in the east and north sides of the monastery (Kroshchenko, 1996, pp. 220-221). As a result, the territory of the monastery becomes square in the plan with a garden, church and covered by shingle southern and eastern campuses. There were also a wooden 2-stories bell tower with hip roof in the northwestern corner of the monastery's site. A holy gate located in the west and an entrance gate was in the southwestern corner (Fig. 1). The whole monastery was surrounded by a stone fences from the east and north, and from the west and south by a wooden fences with the gate. There were also the shingle-covered wooden buildings such as a storage of firewood, a garage for carts, the stables and a kitchen. From down to the church went long oak staircase. Under the hill in the west of the monastery, a brewery with household, residential buildings and 90 bee houses were placed (Kroshchenko, 1996, p.221) (Fig. 2). The monastic ensemble of monumental buildings located on a high plateau above the pond creating a dominant. The Basilian period ends in 1839 when the monastery was returned to Orthodoxy under pressure of the authorities (Kroshchenko, 1996, p.221).

At the beginning of the twentieth century the monastery consisted of three churches: the main Nativity of Virgin, the warm Three Saints that was constructed with the fraternal cells in 1788 and the Exaltation of the Holy Cross (Tsap, 2016). Monastic structures were not damaged during the World War I, but they were not repaired for a long time that led to the collapse in the early 30's of XX century. In the 20's Basilian monks returned to the monastery and lived there until the destruction during the battle between the UPA and the Germans in the fall of 1943 (Kroshchenko, 1996, p.221). Nowadays, the monastery is in ruins (Fig. 5).

The Church of the Nativity of the Virgin is in an emergency state. Roofs, ceilings and vaults over the main nave and over the choirs are destroyed. Vaults in the lateral naves are wet and have fungus. All walls have damaged brickworks by artillery fire in 1943 and there is significant loss of plaster. Fragments of paintings of the XIII-XIV centuries in the altar part, paintings in the other parts of church, some sculptural decorations and the whole carpentry had been lost. Some reconstruction works were carried out in a fraternal building attached to the church. New roof structures were constructed and covered with metal galvanized sheets. Wooden ridge turret with a cross above the central part was done. The fraternal campus functions as Orthodox Church of the Kyiv Patriarchate. 


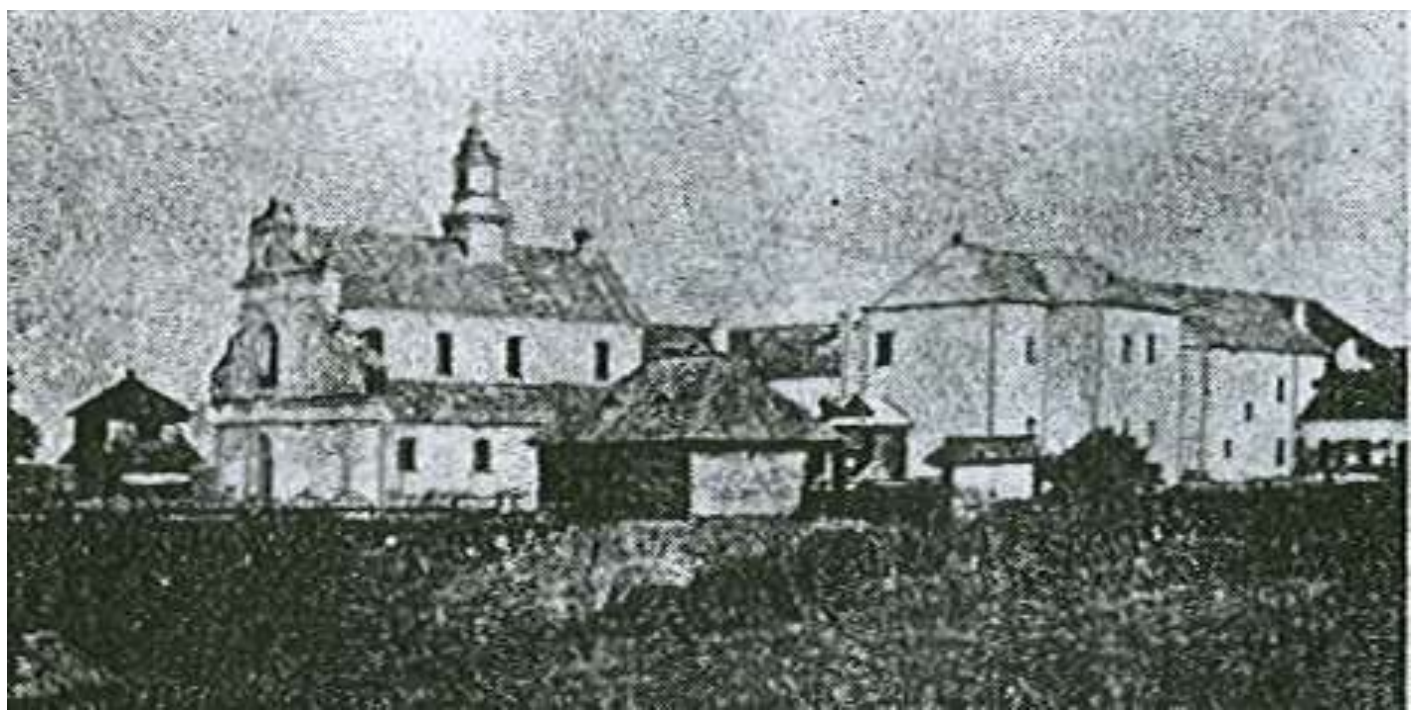

Fig. 1. View of the Monastery of the Nativity of the Virgin in Zagoriv from the southwest. Photo by A.Prachov in 1886 (L.Kroschenko Zagorivsky monastery of the Nativity of the Virgin. From the history of restoration, $K$ Ukrainoznavstvo 1996, p. 217)

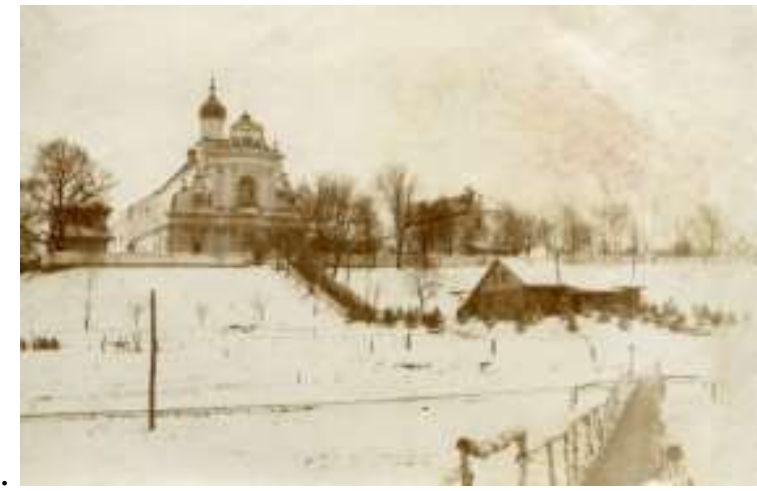

Fig. 2a. View of the monastery of Nativity of Virgin in Zagoriv

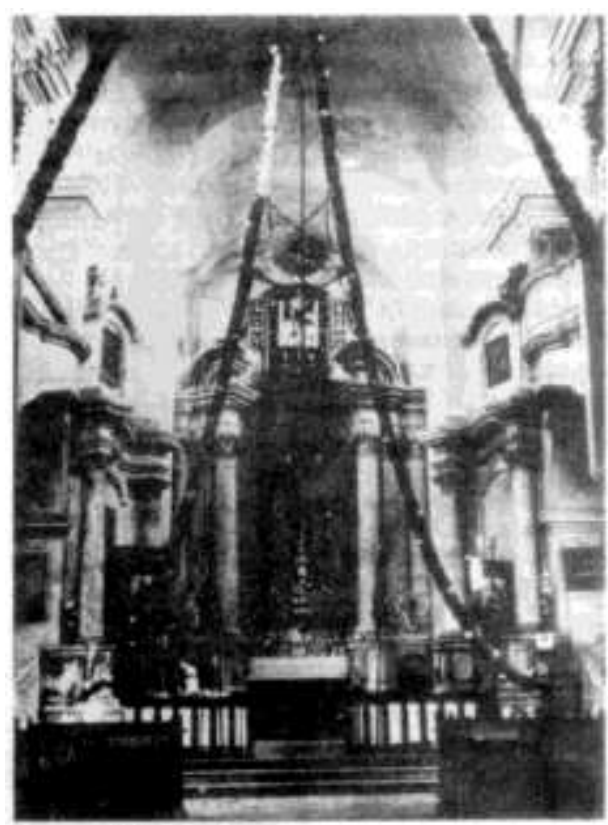

Fig. 3a. The interior of the church of the Nativity of the Virgin in Zagoriv, photo of A. Prahov, 1886.

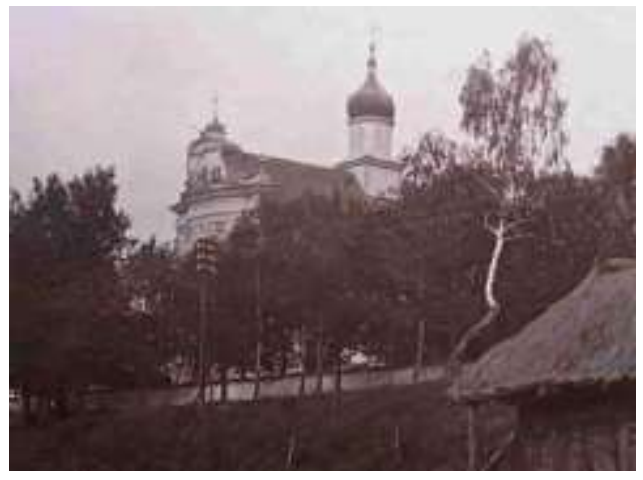

Fig. $2 b$ monastery in 1917 from the west. Photo early $X X$

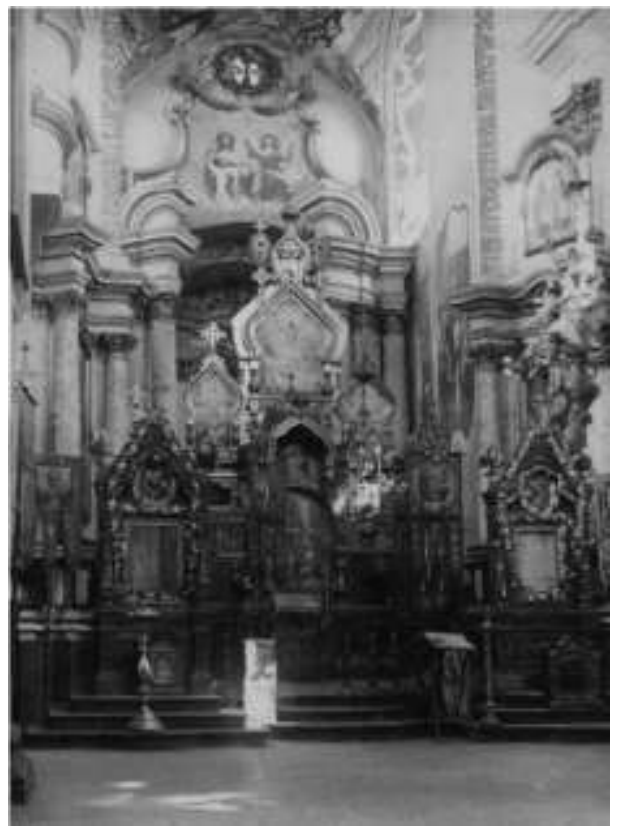

Fig. 3 b. Interior, photo beg.of $X X$ (https://uk.wikipedia.org/wiki) 


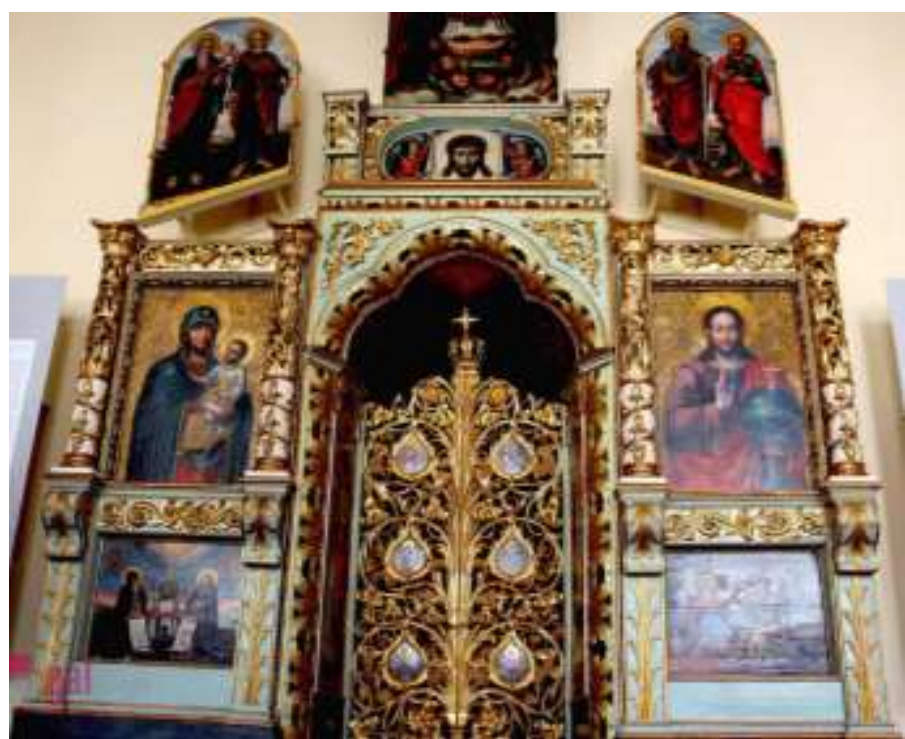

Fig. 4 Fragment of the Voschatinsky (Zagorivsky) iconostasis (made by I. Kondzelevich, photo by O. Lyakhovych), Lviv National Museum of A. Sheptytsky.

An important problem in developing the project of restoration is to show the integral image of the monastic complex that was formed during the XVIII - early XIX centuries. The main objective is to develop a program for the restoration of existing dilapidated monastic buildings based on the scientifically substantiated documentation; to propose the reproduction of certain lost monastic structures without violating the proportional relations as well as to mark the destroyed buildings based on iconographic sources. Another task is to recreate the monastery garden in the style of its origin (XVIII century) with the reproduction of the nature of the placement of plantations and to develop the improvement of the monastery site in accordance to archival materials.

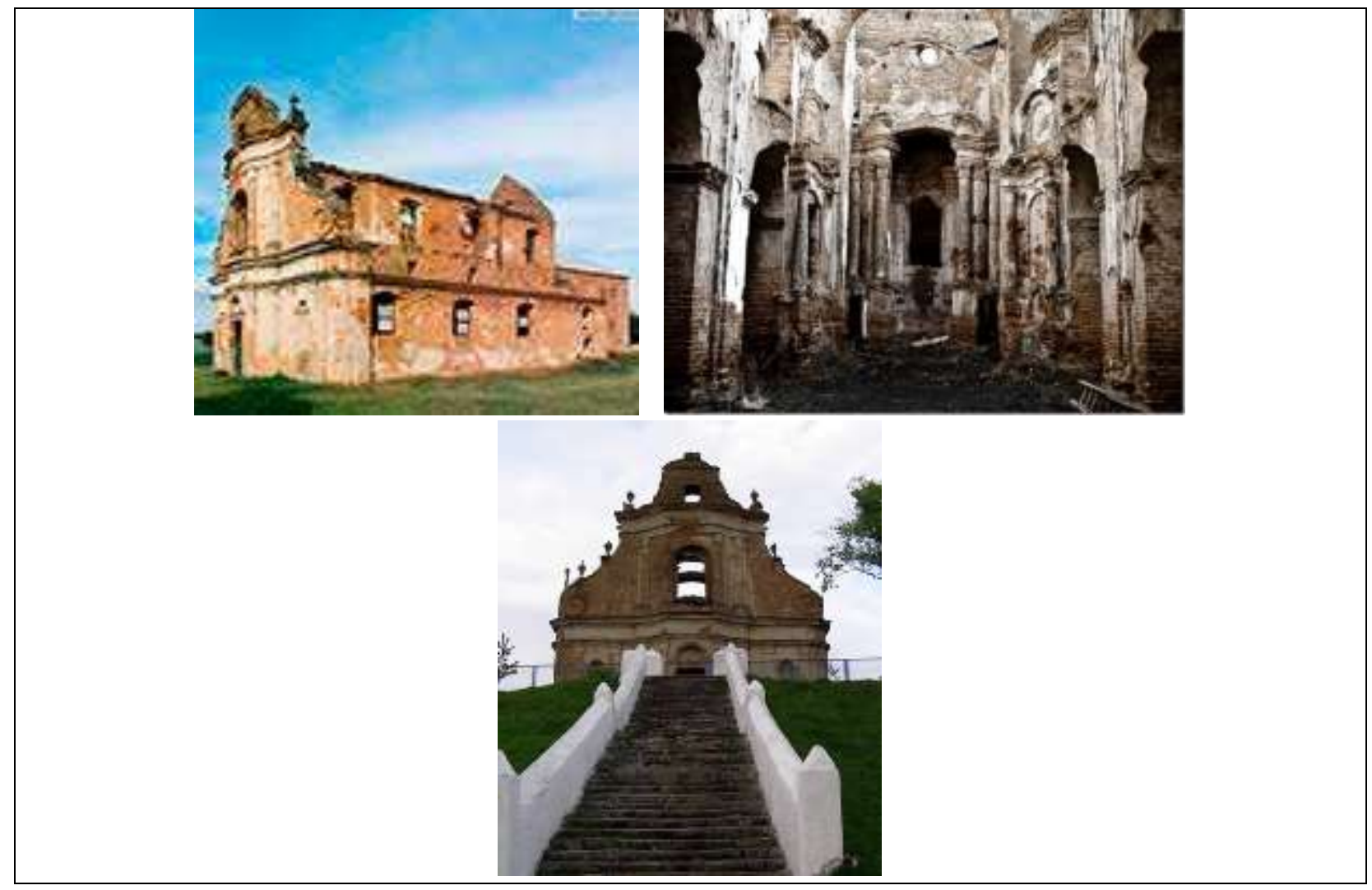

Fig. 5.Ruins of monastery church of the Nativity of the Virgin 


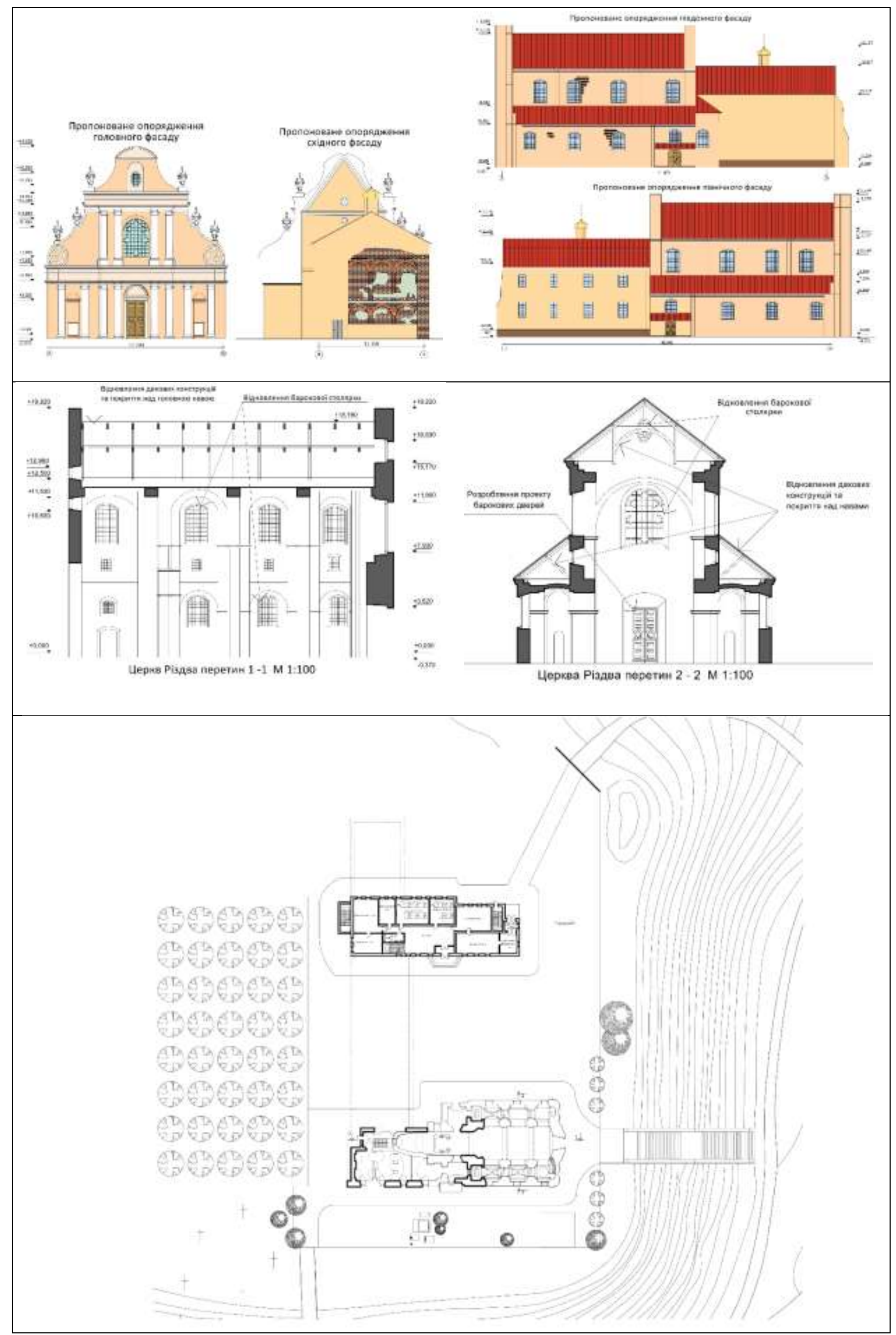

Fig. 6. Project of restoration of the monastic complex in Novy Zagoriv (general plan, facades, section, plans). From master thesis project Poloz. I.O. 
Lviv Polytechnic student Poloz I. O. has developed a thesis project for the restoration of the monastic complex in Novyi Zagoriv with a gradual plan of preserving the monument. The program use the methods of preservation, rehabilitation and restoration of ruined elements of the ensemble and underlines the structures that have an emotional and artistic value for comunity.

\section{Conclusions}

Zagorivsky monastery complex of Nativity of the Virgin takes a prominent place in the history of Volyn. He refers to those monuments that have a comprehensive history of development. It is one of the brightest Baroque ensembles in Volyn. It has not only spiritual but also historical and artistic value. Based on archival iconographic sources and a complete survey of the ruins of the monastery, a comprehensive study was carried out and a project of restoration with a program of actions for preservation and deceleration of the destruction of the monument was elaborated.

\section{References:}

Kroshchenko, L., 1996. Zahorivs'kyy monastyr Rizdva Bohorodytsi na Volyni. In: Tymofienko, V., ed., 1996. From the history of Ukrainian restoration. Kyiv: Ukrayinoznavstvo.

Tripolsky, NN, etc., 1892. Nine hundredth anniversary of Orthodoxy in Volhynia 992-1892. Part 1, Zhytomyr: Tipo-lit. E. P. Lev.

Otkovych, T., 2011, Zahorovs'kyy (Voshchatyns'kyy) ikonostas 1722 roku avtorstva Yova Kondzelevycha. Proceedings of the XVIII International Scientific Conference "Volyn Icon: Research and Restoration". Lutsk. October 27-28, 2011, pp.71-84

Essay on the history of the Basilian Order of St. Jehoshaphat, 1992. Rym: Vydavnytstvo OO. Vasyliyan.

Voznytsky, B., 1967. Tvorchist' ukrayins'koho khudozhnyka Iova Kodzelevycha. Lviv Art Gallery: Exhibitions. Finds, Research. Lviv, p.44.

Kudrytsky, A., 1992. Artists of Ukraine: Encyclopedic reference book, Kyiv, p.313;

Tsap, M., 2016. Rizdvo-Bohorodychnyy cholovichyy monastyr. In: Dzyuba, IM et al., ed., 2003-2016. Encyclopedia of Modern Ukraine: in 30 volumes. Kyiv: NAN Ukrayiny, NTSH, Koordynatsiyne byuro entsyklopediyi suchasnoyi Ukrayiny NAN Ukrayiny. 